\title{
シアキーがなく接合幅をもつ PCa 構造接合部のせん断挙動と耐力評価に 関する研究 \\ STUDY ON SHEAR BEHAVIOUR AND TRANSFER CAPACITY IN PLAIN PRECAST CONCRETE CONNECTION WITH DIFFERENT WIDTHES
}

\author{
斉 \\ 煒*, 槇谷榮次**, 水上 明***, 謝爽**** \\ Wei QI, Eiji MAKITANI, Akira MIZUKAMI \\ and Shuang XIE
}

\begin{abstract}
- Concrete connection specimens subjected to positive-negative cyclic loading were experimentally investigated in order to research their shear transfer mechanism on the effect of different connection width. Parameters among specimens are varied in different connection width, dowel reinforcement diameter, compressive strength of joint mortar and friction along connection interface. Test results, including load-displacement curves, failure state, stress distribution along dowel reinforcement, indicated that concrete and dowel reinforcement reached their plastic ability at relative slip displacement $\delta_{\mathrm{s}}=2 \mathrm{~mm}$, and shear force at slip displacement $2 \mathrm{~mm}$ was conducted by dowel action of connection reinforcement and the capacity of joint mortar due to the friction force along connection interface. Formula of shear transfer capacity was proposed considering bearing pressure capacity and shear friction capacity using plastic dowel and compressive strut resistance mechanisms. The experimental data was compared with proposed shear transfer formula It was concluded that the formula gave a good prediction for experimental results.
\end{abstract}

Keywords : connection width, dowel effect, compressive strut mechanisms, slip displacement 接合幅, ダウェル作用, 圧縮ストラット機構, すべり変位

1. 序

プレキャスト鉄筋コンクリート(以降，PCa 構造)は，接合部の保 有耐力により，建物の耐震性能が大きく左右される。現在，PCa 造 の広範囲におけるる構造規定は「鉄筋コンクリート構造計算規準・同解 説」(文嗝1)に準拠しており，接合部の設計に至っては「壁式プレキャス 卜鉄筋コンクリート造設計規準・同解説」(文葴 2)により詳細が定めら れている。しかし，同設計規準に定められた鉛直接合部基準式は $M$ attock のせん断摩擦理論(文嘀 †)に基づいており，またその他の接合部 せん断耐力は, Jensen の降伏線理論(文献)，そして修正 Mohr-Coulom $b$ の破壊基準(文献 19$)$ より解析されている。これらの評価式では，実際 のPCa 造の施工に必要とされる「接合幅」による影響因子が考慮さ れていない。また，様々な接合幅を有する場合には，その都度，壁 一壁接合部や梁一梁接合部を含む部材実験によって確認されている のが現状である。本研究は，接合幅を変化させた接合部をもつ $\mathrm{PCa}$ 要素試験体を用いて直接せん断実験を行い，接合筋と接合幅が接合 部耐力に及ぼす影響に関して調べることを目的とした。得られた実 験結果に対して，支圧抵抗メカニズムに基づいた接合筋のダウェル 効果と接合部に形成される圧縮ストラットモデルから導かれたせん 断伝達能力評価式を用いて検証した。以下に研究成果を報告する。

\section{2. 実験概要}

\section{1 試験体}

本研究に用いた試験体は，図 1 に示すように，架構式、壁式を問わ ない PCa 構造における鉛直接合部を応力伝達要素として局部的に 想定したもので，試験体の中央部にモルタルと接合筋で $30 、 40 、 60 、$ $100 、 120 、 160 、 200 \mathrm{~mm}$ の幅を有する接合部を構成し，2 ユニシットの $\mathrm{P}$ $\mathrm{Ca}$ 部材で挟む形とした。また，接合幅 $0 \mathrm{~mm}$ として $\mathrm{PCa}-\mathrm{RC}$ 造試 験体とも比較している。今回の実験で使用した接合筋はせん断抵抗 を単純化するため，通し鉄筋としている。また，接合筋径に対する 定着長さの影響をなくす為; 接合筋末端に定着ワッシャーと鉄筋ネ ジで固定した。試験体作成方法として，先に接合筋を 2 ユニットの $\mathrm{PCa}$ 部に渡して配筋し，ユニット部に主筋 4-D16（SD785）とせん 断補強筋 D13(SD785)@50mm で補強し，また加力治具固定用に PC 鋼棒 $17 \phi$ を埋め込み, $\mathrm{PCa}$ 部に30MPaのコンクリートを打設した。 養生脱型した後，一部の試験体は接合境界面に摩擦抵抗をなくすた めに接合面に厚さ $0.3 \mathrm{~mm}$ のテフロンシートを貼って，接合部にモル タルを打設した。製作した試験体は 46 体とし，変動要因は，表 1 に示すように, 接合幅、接合筋径、本数、接合部モルタルの圧縮強度お よび摩擦の有無とした。

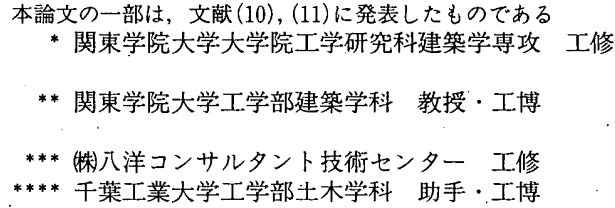

Graduate Student, Dept. of Arch., Grad., School of Eng., Kanto:Gakuin University, M. Eng.

Prof., Department of Architecture, Faculty of Engineering, Kanto-Gakuin University, Dr. Eng.

Hachiyo Consultant Corporation, M. Eng.

Research Assoc., Chiba Institute of Technology, Dr. Eng. 


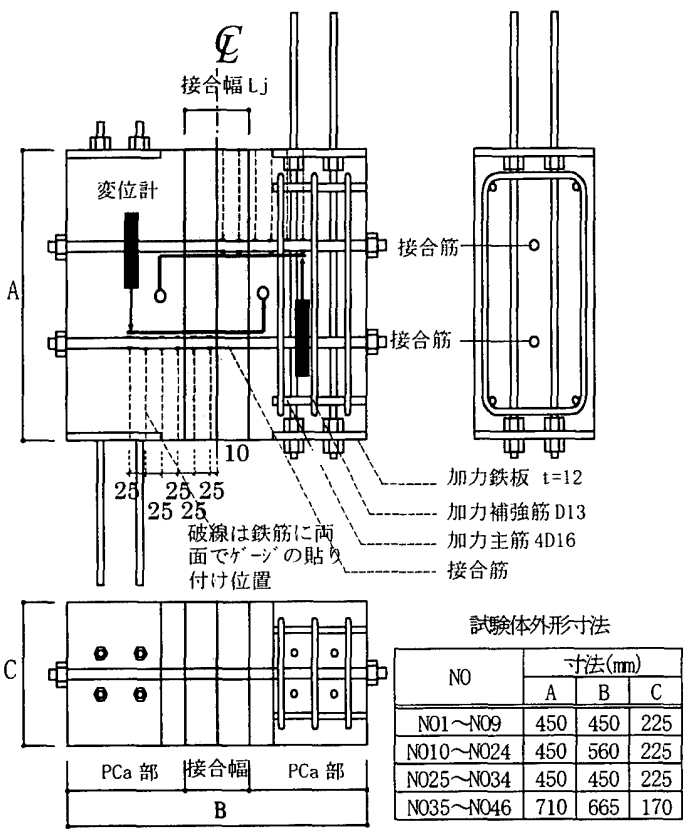

図 1 試験体及び計測方法

表 1 試験体一覧表

\begin{tabular}{|c|c|c|c|c|c|c|c|c|c|}
\hline \multirow[b]{2}{*}{$\mathrm{No}$} & \multirow[b]{2}{*}{ 試験体名 } & \multicolumn{3}{|c|}{ 変動要因 } & \multirow[b]{2}{*}{ No } & \multirow[b]{2}{*}{ 試枒体名 } & \multicolumn{3}{|c|}{ 変動要因 } \\
\hline & & $\begin{array}{c}\text { 接合福 } \\
\text { (min) }\end{array}$ & 接合筋 & $\begin{array}{l}\text { 接合 } \\
\text { 媔力 }\end{array}$ & & & $\begin{array}{c}\text { 接合 } \\
\text { 幅 } \\
(\mathrm{mm})\end{array}$ & 接合筇 & \begin{tabular}{|l} 
接同 \\
媔摩力
\end{tabular} \\
\hline & JPC00- $19 \times 4-30$ & 0 & & & 24 & JPC200-16×2-30 & 200 & $016 \times 2$ & なL \\
\hline & JPC30-19×4-30 & 30 & $\mathrm{D} 19 \times 4$ & なし & 25 & PNO00-19×4-30 & 0 & & \\
\hline 3 & JPC90-19×4-30 & 90 & & & 26 & P:15-19x4-30 & 15 & & \\
\hline & $\mathrm{JPC} 00-19 \times 2-30$ & 0 & & & 27 & $P: 30-19 \times 4-30$ & 30 & & 有り \\
\hline & $\mathrm{JPC} 30-19 \times 2-30$ & 30 & & & 28 & PN60-19×4-30 & 60 & & \\
\hline 6 & JPC90-19×2-30 & 90 & $D 19 \times 2$ & 有り & 29 & PN120-19×4-30 & 120 & & \\
\hline 7 & JPC00-19×2-40 & 0 & & & 30 & PT00-19×4-30 & 0 & & \\
\hline 8 & JPC30-19×2-40 & 30 & & & 31 & PT15-19×4-30 & 15 & & \\
\hline 9 & $J P C 90-19 \times 2-40$ & 90 & & & 32 & PT30-19 $\times 4-30$ & 30 & & なし \\
\hline & JPC00-10×2-30 & 0 & & & 33 & PT60-19×4-30 & 60 & & \\
\hline & $\mathrm{JPC} 30-10 \times 2-30$ & 30 & & & 34 & PT120-19.4-30 & 120 & & \\
\hline & JPC60-10×2-30 & 60 & D $10 \times 2$ & & 35 & P:00-19×2-30 & 0 & & \\
\hline 13 & JPC120-10×2-30 & 120 & & & 36 & $P \Uparrow 40-19 \times 2-30$ & 40 & & \\
\hline & JPC200-10×2-30 & 200 & & & 37 & P.60-19×2-30 & 60 & & \\
\hline & JPC00-13×2-30 & 0 & & & 38 & PN100-19×2-30 & 100 & & \\
\hline 16 & $\mathrm{JPC} 30-13 \times 2-30$ & 30 & & & 39 & $P \times 160-19 \times 2-30$ & 160 & & \\
\hline 17 & JPC60-13×2-30 & 60 & D13 $\times 2$ & なし & 40 & P.200-19×2-30 & 200 & & \\
\hline 18 & $\mathrm{JPCl} 20-13 \times 2-30$ & 120 & & & 41 & PT00-19×2-30 & 0 & & \\
\hline & $J P C 200-13 \times 2-30$ & 200 & & & 42 & PT40-19 $192-30$ & 40 & & \\
\hline 20 & $J P C 00-16 \times 2-30$ & 0 & & & 43 & PT60-19×2-30 & 60 & & \\
\hline & JPC30-16 $\times 2-30$ & 30 & $6 \times$ & & 44 & PT100-19×2-30 & 100 & & \\
\hline & JPC60-16 $\times 2-30$ & 60 & & & 45 & PT160-19×2-30 & 160 & & \\
\hline $23 !$ & & 20 & & & & $9 \times 2-30$ & 200 & & \\
\hline
\end{tabular}

\section{2 加力方法と測定方法}

加力方法は，図 2 に示すように試験体を垂直に設置し，試験体の $P C a$ 部に埋め込えだ $P C$ 鋼棒によって，水平方向から接合部の中心 線上に，押し引き用のオイルジャッキを用いてせん断力を与える $\mathrm{S}$ 型加力方式で行う。試験体を設置したときに使用した鈶直方向のジ ヤッキは実験中に接合面に垂直方向に外力を作用させないようにし た。加力スケジュールは, No1〜No34 試験体は, 変位制御により, 相対すべり変位(以降，すべり変位と呼ぶ) $\pm 0.5,1,2,4,6,8,10,12 \mathrm{~mm}$ の 8 サイクルに+15mmの押し切りを加えた変位制御の正負交番繰り返 し載荷とした(一部の試験体では終局変形を+12mm まで制御した)。 No35〜No46 試験体は，一方向単調水平力を加えて, $15 \mathrm{~mm}$ まで変位 制御し載荷した。

測定方法は，図１に示すように，2つの $P C a$ 部に設置した高感度 変位計によって $P C a$ 部材間のすべり変位を測定し, それぞれの平均 を 2 つの $P C a$ 部の相対すべり変位 $\delta s$ とする。また, 荷重は加力用
のオイルジャッキに取り付けた IMN ロードセルによって測定し， 接合筋両面に貼付したワイヤーストレインゲージによって接合面近 傍における接合筋各部のひずみを測定する(間隔は図 1 に示す)。

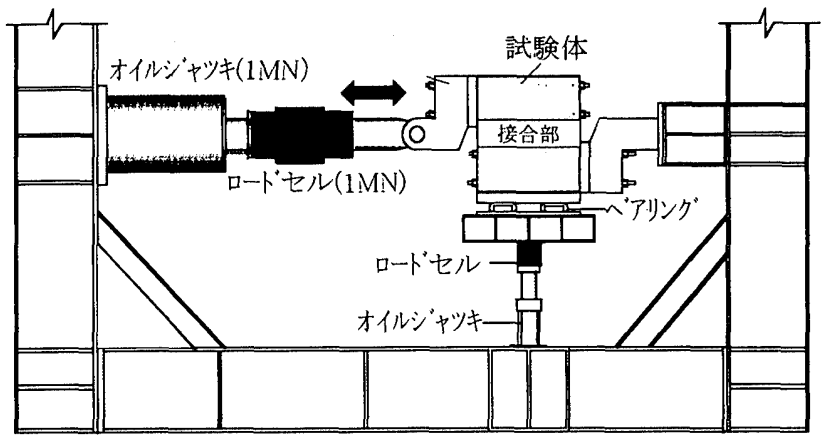

図 2 加力装置図

\section{3 材料性状}

試験体に使用した $P C a$ 部コンクリート，接合部モルタルの材料性 状を表 2 に示した。ここで，Ecはコンクリート圧縮強度の $1 / 4$ の応 力度とひずみによって算定した。接合筋の材料性状を表 3 に示す。

表2 コンクリート材料性状

\begin{tabular}{|l|l|l|l|l|l|}
\hline & $\mathrm{PCa}$ 部コンクリート & 接合部モルタル & $\mathrm{PCa}$ 部コンクリート & 接合部モルタル \\
\cline { 2 - 4 }
\end{tabular}

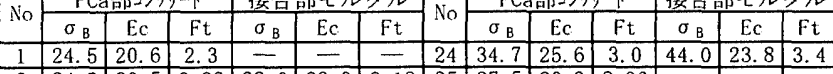
\begin{tabular}{|c|c|c|c|c|c|c|c|c|c|c|c|c|}
\hline & 24.5 & 20.6 & 2.3 & - & - & & 24.5 & 20.9 & 2.36 & - & - & - \\
\hline 2 & 24.8 & 20.5 & 2.38 & 32.0 & 22.0 & 2.12 & 25 & 27.5 & 20.9 & & -
\end{tabular}

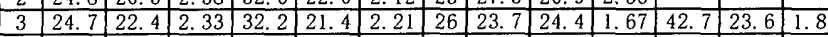
\begin{tabular}{|c|c|c|c|c|c|c|c|c|c|c|c|c|c|}
\hline 4 & 29.9 & 23.8 & 2.72 & - & - & - & 27 & 24.3 & 26.3 & 1.66 & 45.8 & 23.8 & 2.9 \\
\hline 5 & 33.4 & 26.3 & 3.13 & 42.9 & 21.3 & 2.94 & 28 & 25.9 & 25.4 & 2.25 & 32.1 & 22.4 & 2.9 \\
\hline
\end{tabular} \begin{tabular}{|c|c|c|c|c|c|c|c|c|c|c|c|c|c|}
\hline 5 & 33.4 & 26.3 & 3.13 & 42.9 & 21.3 & 2.94 & 28 & 25.9 & 25.4 & 2.25 & 32.1 & 22.4 & 2.9 \\
\hline 6 & 33.0 & 36.2 & 3.17 & 37.2 & 23.4 & 2.1 & 29 & 24.1 & 24.6 & 1.67 & 30.2 & 22.7 & 1.9 \\
\hline
\end{tabular} \begin{tabular}{|c|c|c|c|c|c|c|c|c|c|c|c|c|c|}
\hline 7 & 45.1 & 23.8 & 3.64 & - & - & - & 30 & 27.5 & 20.9 & 2.36 & - & - & - \\
\hline 8 & 47.2 & 119 & 3.54 & 47.4 & 21.8 & 2.82 & 31 & 23.3 & 24.4 & 1.67 & 47.2 & 22.4 & 1.4 \\
\hline
\end{tabular} \begin{tabular}{|l|l|l|l|l|l|l|l|l|l|l|l|l|l|}
\hline 8 & 47.2 & 21.9 & 3.54 & 47.4 & 21.8 & 2.82 & 31 & 23.3 & 24.4 & 1.67 & 47.2 & 22.4 & 1.4 \\
\hline 9 & 49.4 & 21.7 & 3.4 & 47.4 & 19.1 & 3.4 & 32 & 24.3 & 26.3 & 1.66 & 45.8 & 23.7 & 2.9 \\
\hline 10 & 27.8 & 25.4 & 2.1 & 38.8 & 25.3 & 3.3 & 33 & 25.9 & 25.4 & 2.25 & 42.7 & 21.4 & 1.9 \\
\hline
\end{tabular}

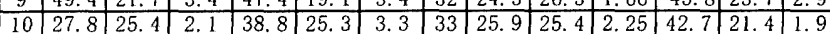
\begin{tabular}{|l|l|l|l|l|l|l|l|l|l|l|l|l|l|}
\hline 10 & 27.8 & 25.4 & 2.1 & 38.8 & 25.6 & 3.3 & 3.6 & 1.67 & 37.8 & 23.7 & 3.6 \\
\hline 1 & 29.1 & 25.6 & 2.3 & 33.4 & 22.6 & 3.2 & 34 & 24.1 & 24.6 & 1.6 & \\
\hline
\end{tabular}

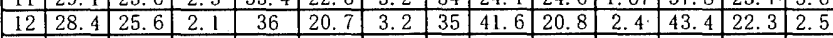
\begin{tabular}{|l|l|l|l|l|l|l|l|l|l|l|l|l|l|}
13 & 34.7 & 25.6 & 3.0 & 44.0 & 23.8 & 3.4 & 36 & 42.6 & 21.7 & 2.71 & 39.1 & 23.3 & 1.8 \\
\hline
\end{tabular} \begin{tabular}{|c|c|c|c|c|c|c|c|c|c|c|c|c|c|c|}
\hline 14 & 34.7 & 25.6 & 3.0 & 44.0 & 23.8 & 3.4 & 37 & 41.6 & 21.4 & 2.43 & 39.1 & 22.9 & 1.8 \\
\hline 15 & 27.8 & 25.4 & 2.1 & 38.8 & 25.3 & 3.3 & 38 & 38.3 & 22.1 & 2.6 & 40.8 & - & 3.2 \\
\hline
\end{tabular}

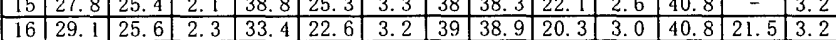

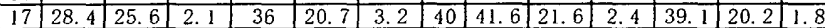

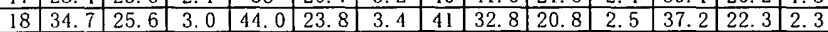
\begin{tabular}{|l|l|l|l|l|l|l|l|l|l|l|l|l|l|}
\hline 19 & 34.7 & 25.6 & 3.0 & 44.0 & 23.8 & 3.4 & 42 & 33.3 & 21.7 & 2.1 & 37.3 & 23.3 & 1.7 \\
\hline 2 & 27.8 & 25.4 & 2.1 & 38.8 & 25.3 & 3.3 & 43 & 39.7 & 21.4 & 2.1 & 37.3 & 22.9 & 1.7 \\
\hline
\end{tabular} \begin{tabular}{|l|l|l|l|l|l|l|l|l|l|l|l|l|l|}
\hline 20 & 27.8 & 25.4 & 2.1 & 38.8 & 25.3 & 3.3 & 43 & 39.7 & 21.4 & 2.1 & 37.3 & 22.9 & 1.7 \\
\hline 21 & 29.1 & 25.6 & 2.3 & 33.4 & 22.6 & 3.2 & 44 & 38.9 & 22.1 & 3.0 & 40.8 & 20.7 & 3.2 \\
\hline
\end{tabular} \begin{tabular}{|l|l|l|l|l|l|l|l|l|l|l|l|l|l|}
\hline 21 & 29.1 & 25.6 & 2.3 & 33.4 & 22.6 & 3.2 & 44 & 38.9 & 22.1 & 3.0 & 40.8 & 20.7 & 3.2 \\
\hline
\end{tabular}

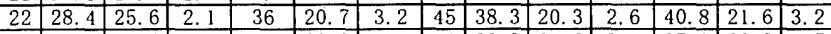
\begin{tabular}{|l|l|l|l|l|l|l|l|l|l|l|l|l|l|}
\hline 23 & 34.7 & 25.6 & 3.0 & 44.0 & 23.8 & 3.4 & 46 & 33.3 & 21.6 & 2.1 & 37.3 & 20.2 & 1.7 \\
\hline
\end{tabular}

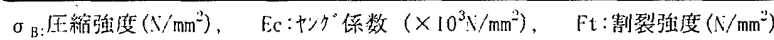

表3 鉄筋の機械的性質

\begin{tabular}{|c|c|c|c|c|c|c|c|c|c|}
\hline No & 種類 & $\sigma_{y}$ & $\sigma_{u}$ & Ey & No & 種類 & $\sigma_{y}$ & $\sigma_{u}$ & Ey \\
\hline \hline
\end{tabular} \begin{tabular}{|l|l|l|l|l|l|l|l|l|l|}
\hline \hline No1 - No9 & D19 & 393.1 & 593.6 & 195.4 & No20-No24 & D16 & 371.0 & 595.0 & 194.8 \\
\hline
\end{tabular} \begin{tabular}{|l|l|l|l|l|l|l|l|l|l|}
\hline No10-No14 & D10 & 367.4 & 541.4 & 199.9 & No25-No34 & D19 & 392.8 & 549.8 & 194.2 \\
\hline
\end{tabular} \begin{tabular}{|l|l|l|l|l|l|l|l|l|l|}
\hline No15-No19 & D13 & 373.1 & 526.6 & 199.4 & No35-No46 & D19 & 405.2 & 558.3 & 217.1 \\
\hline
\end{tabular} $\sigma_{y}:$ 降伏強度 $\left(\mathrm{N} / \mathrm{mm}^{2}\right), \sigma_{a}:$ 引張強度 $\left(\mathrm{N} / \mathrm{mm}^{2}\right)$, Ey : やクグ係数 $\left(\times 10^{3} \mathrm{~N} / \mathrm{mm}^{2}\right)$

\section{3. 実験結果}

\section{1 ひび割れ性状と破壊性状}

テフロンシートを施している試験体では，図３に示すように，加 力初期より初ひび割れが接合部両側の接合面に沿って生じた。接合 幅が大きくなるにしたがって,初ひび割れ発生時の荷重が低くなる。 その後接合面に沿ってすべり変位が増大し，ジョイントコンクリー 卜部に縦方向のひび割れが発生した。これは，接合筋直下において 接合面と塑性ヒンジ間のコンクリートに生じる支圧抵抗で $\mathrm{PCa}$ 部 材閒のせん断伝達が行われると考えられる。テフロンシートを施し ていない試験体では，接合幅がゼロ及び小さい試験体には，接合部 片面に初ひび割れ発生した（一面せん断）に対して，接合幅が大き い試験体には，初ひび割れが接合部両側で接合面に沿って同時に発 生した（二面せん断）(表 4 に示す)。その後, 接合部に斜めひび割 


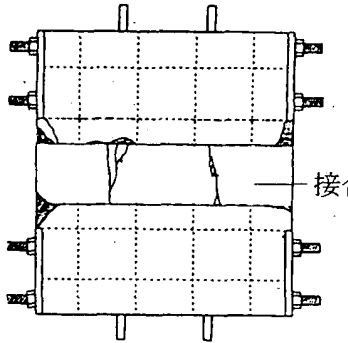

テフロシートを施している試験体 JPC120-16×2-30 破壊性状

図 3

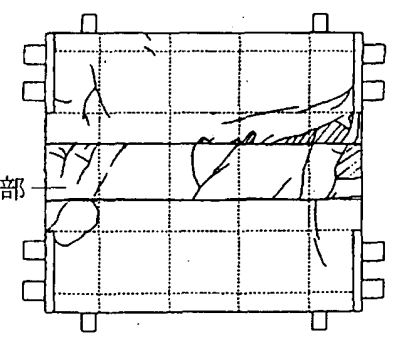

テフロシートを施していない試験体 JPC90-19 $\times 2-30$ 破壊性状 試験体の破壊性状図
れも発生していると同時に, 一面せん断を生じた一部の試験体を除 くと, 殆どの試験体において接合部両側の接合面に沿ってひび割れ が進展することが見受けられる。これはせん断抵抗が鉄筋のダウエ ル抵抗と接合筋の引っ張り力によって接合部に作用する圧縮摩擦抵 抗(接合筋によるせん断摩擦抵抗と呼ぶ)でせん断抵抗が行われてい ると考えられる。

\section{2 荷重一変位曲線}

テフロンシートを貼って接合界面に摩擦が生じないようにした 試験体では，図 4 に示すように，加力初期より滑らかなせん断伝達 とすべり変位の増大が見られるが，すべり変位の増大によって耐力 が緩やかに上昇して，急激な耐力低下が見られずに最大変位に達す る。殆どの試験体は滑り変位 $2 \mathrm{~mm}$ までに接合筋が降伏する。テフ ロンシートを施していない試験体では, 図 5 に示すように, 接合界 面のコンクリートの付着抵抗によって, 加力開始後, 滑り変形の進 行は見られず，ほぼ荷重軸に沿って耐力上昇を続けているが，コン クリート界面の付着摩擦力が失われるとすべりが進行し, 耐力が急 激に低下し，その後再び耐力か徐々に増大し，最大変位に達する。 接合筋の降伏は，す心゙り变位 $2 \mathrm{~mm}$ までに確認されている。鉄筋の 降伏変形の進行によって, 一部の試験体では, すべり変位 $2 \mathrm{~mm}$ 近 傍で接合筋沿いに生じた接合部割裂ひび割れと同時に耐力低下が記 録されている。各試験体では，接合幅の違いによって，各試験体の 最大耐力が変化するが, 荷重-変位曲線の履歷はほぼ同様な傾向を示 すことが認められる。

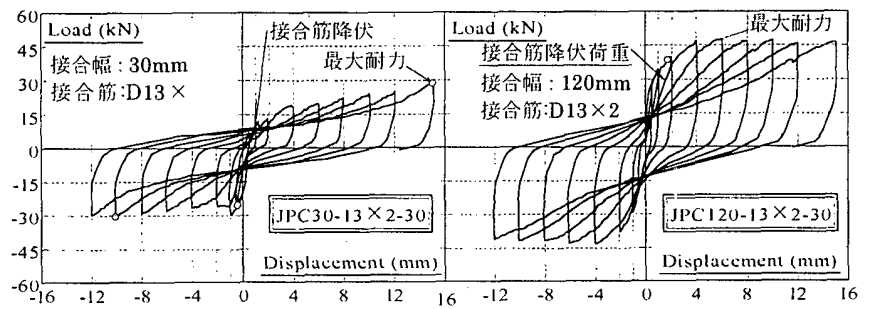

図 4 テフロンシートを施している試験体の荷重一変位曲

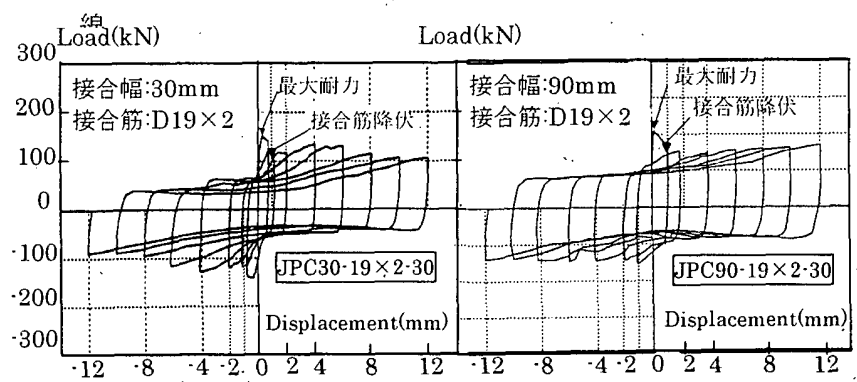

図 5 テフロンシートを施していない試験体の荷重一変位曲線

\section{3 接合筋における応力状況}

接合筋の裏および表に貼り付けたゲージによって鉄筋のひずみ変 化を測定した。ここで, 各測定点における表裏ひずみの和の平均を 軸力によるひずみ, 差の $1 / 2$ を曲げによるひずみとして弾性範囲に おいて換算を行った。接合筋を受ける軸力と曲げモーメントは下式 に示した。

$$
\begin{aligned}
& N=\frac{\left(\sigma_{\text {然 }}+\sigma_{\text {要 }}\right)}{2} \cdot \frac{\pi \cdot d r^{2}}{4} \quad \text { (弹性軸方向力) } \\
& M=\frac{\left(\sigma_{\text {烈 }}-\sigma_{\text {基 }}\right)}{2} \cdot \frac{\pi \cdot d r^{3}}{32} \quad(\text { 弾性曲げモーメント })
\end{aligned}
$$

各試験体の接合面近傍では, 加力初期より鉄筋の曲げモーメント, 軸力が同時に作用している，図6に示すように，同じ接合筋 $(2 \times \mathrm{D}$ 13）をもつ二体の試験体，接合幅が小さい場合（図 6 の左側に示す ように, 接合幅 $60 \mathrm{~mm}$ ）では, $\mathrm{PCa}$ 部にU 字状の曲げモーメント分 布を生じ，接合部を挟んで左右 PCa 部(左図の(1),(2))の曲げモーメン トが極大となる点が存在している。接合幅が大きい場合(図 7 右図に 示すように，接合幅 $120 \mathrm{~mm}$ )では, $\mathrm{PCa}$ 部, 接合部ともに非対称の $\mathrm{S}$ 字状の曲げモーメント分布を示し，両接合面を挟んで 4 個所(右図の (1),(2)(3),(4))で曲げモーメントが極大となる点が存在している。これ らモ一メントが極大になる点で降伏ひずみ以降に塑性ヒンジが形成 されると考えられる。同時に軸力は曲げモーメントが大きい時に大 きな引張りカを受けていることが確認された。接合笳にD13 用いた 試験体について，接合幅 $0,30,60,120,200 \mathrm{~mm}$ 試験体(No.15 19)の軸 力を見ると，それぞれ 37.4,13.4,8.4,19.6,11.3 k N と発現した。接合筋 径に関して，接合筋径が太径になるにつれて，その最大曲げモーメ ント部は接合境界面より離れていくのが判る。接合筋の降伏時に生 じる接合界面からヒンジ部までの距䧺は接合筋径に比例しており, この事実は，既往の論文(文解7)でも報告されている。
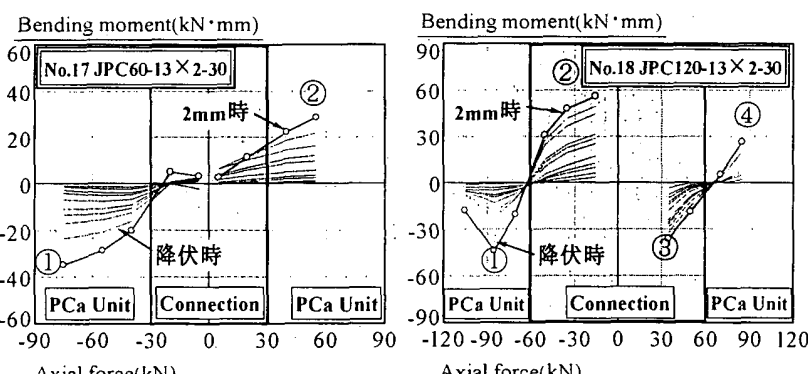
Axial force $(\mathrm{kN})$
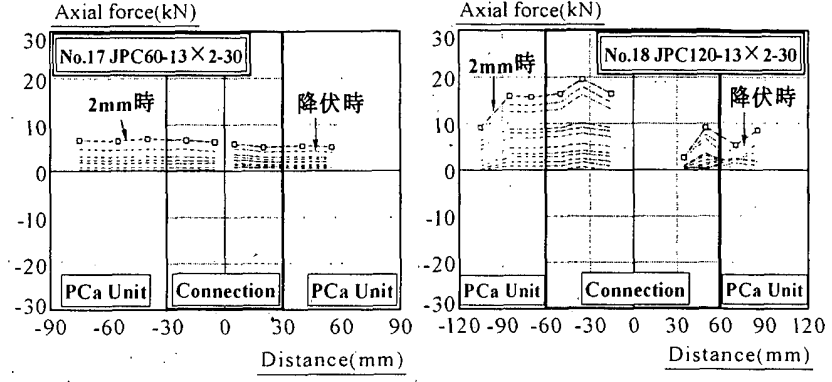

接合幅小さい場合 $(\mathrm{Lj}=60 \mathrm{~mm})$ ，接合幅が大きい場合 $(\mathrm{Lj}=120 \mathrm{~mm})$. 図 6 接合筋における曲げモーメントと軸力分布

\section{4 すべり変位 $2 \mathrm{~mm}$ 時のせん断耐力および最大せん断耐力}

テフロンシートを施している試験体に対して，摩擦が生じないた め，せん断抵抗は接合筋のダウエル抵抗のみで行われている。接合 筋のダウェル抵抗は; 滑り变位がある程度以上になると, 耐力を十 分に発揮する抵抗特性を示す。接合部の滑り変位に対して，既往の 
文献 (文献 13)によると，プレキャスト梁, 社,耐震壁の実験によって， 限界変位時(柱は最大耐力時, 梁は $R=1 / 50$, 耐震壁は $R=1 / 200$ 時)に 生じるプレキャスト接合部の滑り変位は最大 $1 \sim 2 \mathrm{~mm}$ で，部材全体 変形に及ぼす影響は極めて小さいことが報告されている。これより， 接合部の滑り変位は最大 $2 \mathrm{~mm}$ で接合部のせん断抵抗を評価するこ とが望ましいと考えられる。一方, 接合幅の存在により(特に接合幅 大きい場合, 接合筋は 4 個所で塑性ヒンジが形成された時), 接合部 両側に一面また二面でせん断破壊を発生する可能性がある。従って， 滑り変位によってせん断抵抗の評価が難しくなる。ここで，表 4 に 示すように, 多数の試験体は滑り変位 $2 \mathrm{~mm}$ 以内に接合筋が降伏し て，その後，塑性ヒンジが形成されることによって，鉄筋のダウエ ル抵抗が十分に発揮される意味で，接合幅と関係なく，また材料強 度、部材寸法にも依存せず，従来の $2 \mathrm{~mm}$ 時の耐力を対象として，せ ん断抵抗評価が行われた。

\begin{tabular}{|c|c|c|c|c|c|c|c|c|c|}
\hline \multirow[b]{2}{*}{ NO } & \multicolumn{2}{|c|}{ 降伏時 } & \multirow{2}{*}{$\begin{array}{l}2 \mathrm{~mm} \text { 時 } \\
\text { 耐力 } \\
\text { (KN) }\end{array}$} & \multirow[b]{2}{*}{ すべり面 } & \multirow[b]{2}{*}{ NO } & \multicolumn{2}{|c|}{ 降伏時 } & \multirow{2}{*}{$\begin{array}{c}2 \mathrm{~mm} \text { 時 } \\
\text { 耐力 } \\
\text { (KN) }\end{array}$} & \multirow[b]{2}{*}{ すべり面 } \\
\hline & $\begin{array}{l}\text { 荷重 } \\
(\mathrm{KN})\end{array}$ & $\begin{array}{l}\begin{array}{l}\text { 変位 } \\
(\mathrm{mm})\end{array} \\
\end{array}$ & & & & $\begin{array}{l}\text { 荷重 } \\
(\mathrm{KN})\end{array}$ & $\begin{array}{l}\begin{array}{l}\text { 変位 } \\
(\mathrm{mm})\end{array} \\
\end{array}$ & & \\
\hline 1 & 113.7 & 0.41 & 121.5 & 一面 & 24 & 35.5 & 2.41 & 31.3 & 二面 \\
\hline 2 & 78.4 & 0.52 & 84.3 & \multirow[b]{2}{*}{ 二面 } & 25 & 217.5 & 0.37 & 200.9 & \multirow{2}{*}{ 一面 } \\
\hline 3 & 69.6 & 2.10 & 74.5 & & 26 & 196.8 & 0.65 & 184.2 & \\
\hline 4 & 175.4 & 1.10 & 184.8 & 一面 & 27 & 177.3 & 1.14 & 178.4 & \multirow{3}{*}{ 二面 } \\
\hline 5 & 113.7 & 1.03 & 115.4 & \multirow{2}{*}{ 二面 } & 28 & 208.6 & 0.59 & 198.0 & \\
\hline 6 & 118.6 & 2.10 & 118.6 & & 29 & 227.3 & 0.92 & 220.4 & \\
\hline 7 & 123.5 & 1.47 & 208.4 & \multirow{2}{*}{ 一面 } & 30 & 146.8 & 1.76 & 161.7 & 一面 \\
\hline 8 & 124.5 & 1.90 & 125.5 & & 31 & 96.9 & 1.58 & 104.4 & \multirow{4}{*}{ 二面 } \\
\hline 9 & 118.6 & 1.80 & 127.5 & 二面 & 32 & 84.7 & 1.34 & 95.1 . & \\
\hline 10 & - & - & 29.0 & 二面 & 33 & 112.3 & 0.81 & 114.7 & \\
\hline 11 & 12.9 & 0.92 & 18.7 & \multirow{4}{*}{ 二面 } & 34 & 135.9 & 1.89 & 138.6 & \\
\hline 12 & 16.7 & 1.22 & 17.3 & & 35 & 134.2 & 0.94 & 116.6 & 一面 \\
\hline 13 & 16.9 & 0.58 & 18.7 & & 36 & 102.4 & 0.32 & 90.2 & \multirow{4}{*}{ 二面 } \\
\hline 14 & 18.2 & 3.14 & 16.3 & & 37 & 107.7 & 0.63 & 94.6 & \\
\hline 15 & 31 & 0.81 & 41.3 & 二面 & 38 & 124.6 & 0.21 & 100.5 & \\
\hline 16 & 25.6 & 0.41 & 26.1 & \multirow{4}{*}{ 二面 } & 39 & 129.7 & 0.79 & 118.6 & \\
\hline 17 & 13.3 & 2.35 & 28.2 & & 40 & 157.2 & 0.48 & 128.4 & 一面 \\
\hline 18 & 38.4 & 1.81 & 39.9 & & 41 & 80.2 & 1.84 & 90.7 & \multirow{6}{*}{ 二面 } \\
\hline 19 & 29.5 & 1.34 & 27.7 & & 42 & 50.7 & 1.18 & 51.9 & \\
\hline 20 & 36.4 & 0.60 & 62.0 & 一面 & 43 & 51.8 & 1.47 & 45.1 & \\
\hline 21 & 14.8 & 1.16 & 23.2 & \multirow{3}{*}{ 二面 } & 44 & 72.9 & 0.57 & 52.4 & \\
\hline 22 & 30.5 & 0.57 & 33.9 & & 45 & 59.2 & 1.94 & 74.5 & \\
\hline 23 & 30.5 & 0.32 & 46.9 & & 46 & 77.1 & 0.54 & 86.2 & \\
\hline
\end{tabular}

また，テフロンシートを施している試験体に対して，接合筋とコ ンクリートの組み合わせ抵抗を考慮して，せん断耐力 $\tau_{d}$ を $\sqrt{ }\left(\sigma_{B j}\right.$. $\left.\sigma_{v}\right)$ で除して無次元化して評価を行う。図 7 に示すように，同一接 合筋径を持つ試験体では，接合幅の違いによって，せん断耐力も変 動する。変動曲線が概权 U か L 字形になって、U 字型分布の場合， 接合幅が大きくなると，接合幅 0 の試験体の一面せん断耐力まで復 元する傾向が見られる。曲線のトロー(谷部)に相当する位置も接合 筋直径の違いによって異なる。この位置は，接合筋(D10、D13、D16) では接合幅 $30 \mathrm{~mm}$ で生じ，又接合筋 D19 では接合幅 $60 \mathrm{~mm}$ で生じて いることから，接合幅と接合筋径の組み合わせによって抵抗メカニ ズムの違いが存在するのではないかと推測される。

\section{4. 結果解析と考察}

\section{1 せん断抵抗機構}

シアキーのない PCa 接合部のせん断抵抗要素として，(1)接合部に 新旧コンクリート間の付着抵抗，(2)接合筋のダウェル抵抗，(3)接合 筋によるせん断摩擦抵抗の 3 つの抵抗要素を考える。接合筋のダウ エル抵抗は，滑り変位がある程度以上になると，耐力を十分に発揮 する抵抗特性に対して，コンクリート間の付着抵抗が微小变位で強 度を発揮する脆性的な抵抗特性もある。また，コンクリート間の付

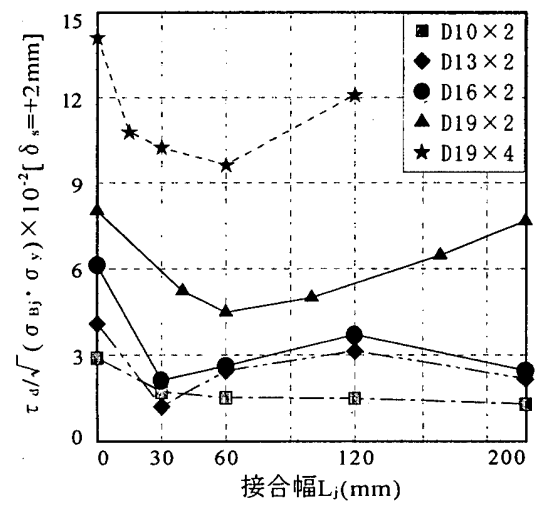

図 7 変位 $2 \mathrm{~mm}$ 時にせん断応力 $\tau_{\mathrm{d}}$ と接合幅 $L j$ の関倸

着抵抗と接合筋による摩擦抵抗は，すべりが発生する時の静態摩擦 とすべりが進行する時の動態摩擦と分けて考え, 実験結果によると, シアキーのない試験体に対して, すべり発生以降の動態摩擦力(接合 筋のせん断摩擦力)は静態摩擦力(コンクリート間の付着力)と比べる と，ある程度は低下するが，大きな差がないことから，動静態摩擦 力は等しいと考える。ここで, 鉄筋のダウェル作用が十分に発揮さ れることを考虑し，すべり $2 \mathrm{~mm}$ 時の耐力を対象として解析する。 そのため，シアキーのない試験体の抵抗機構は，図 8 に示すように 各せん断抵抗の累加と考えられる。

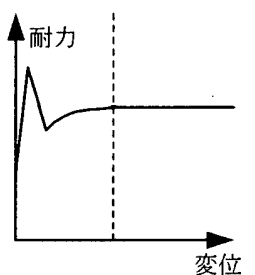

全せん断抵抗

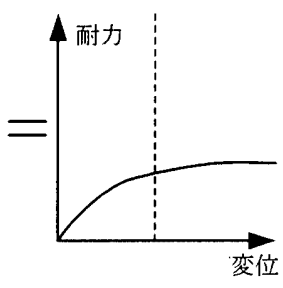

鉄筋のダウェル抵抗

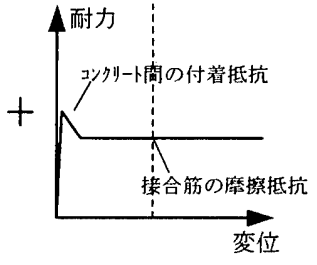

せん断摩擦抵抗
図 8 シアキーのないの試験体おける耐力一変位モデル

\section{2 鉄笳のダウェル抵抗式}

\subsection{1 接合筋のダウェル作用によるせん断抵抗}

$P C a$ 部と接合部コンクリートの接合面がせん断力を受け，両者相 互にすべり変位を生じると，接合筋は，接合面近傍のコンクリート 支圧強度によって，せん断伝達を行う。この際，鉄筋はコンクリー トを支承として，図9に示すように，接合部コンクリートの中央部 に対して，逆対称曲げモーメント分布を形成する。この曲げモーメ ントは，接合幅 $L_{j}$ が小さい場合 $\left(L_{j} \leqq L_{j h}\right)$ か大きい場合 $\left(L_{j}>L_{j b}\right)$ によっ て分布が異なる。鉄筋の曲げモーメント分布において，最大曲げモ 一メントが塑性モーメントに達すると, 最大曲げモーメント部では, 塑性ヒンジが形成される。この際，接合幅が小さい場合は，PCa 部 にのみ塑性ヒンジが形成され，すべり変位は，片面に対して， $\delta s / 2$ となる( $\delta \mathrm{s}$ は二つの $\mathrm{PCa}$ 部の相対滑り変位)。

塑性ヒンジにおける鉄筋の塑性変形(以降，ダウェル変形)によっ て，コンクリートには，コンクリート圧縮強度の数倍の支圧応力が 生じる。接合幅が小さい場合, 接合部のコンクリート支圧応力は小 さいので無視すると，図 9 に示すように，接合面から塑性ヒンジの 間に生じる支圧応力を矩形分布と仮定する。また，接合幅が大きい 場合は，接合面から $P C a$ 部及びジョイントコンクリート部の塑性ヒ ンジ間に生じる支圧応力と接合部の塑性ヒンジから中央までの支圧 


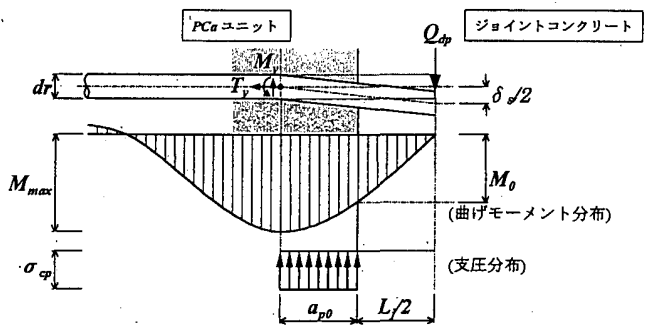

(a) 接合幅小さい場合

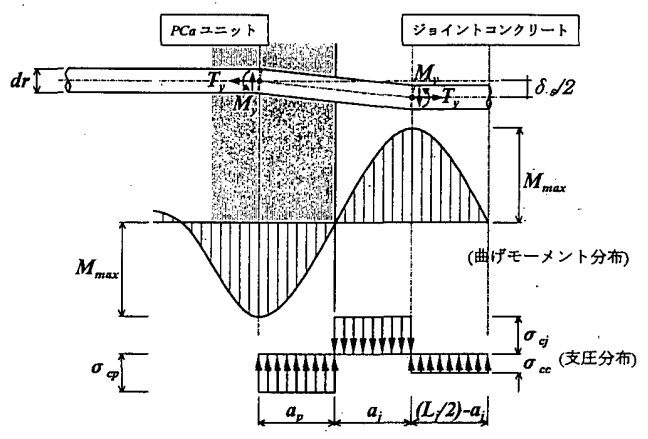

(b) 接合幅大きい場合

図 $9 \mathrm{PCa}$ 接合部における支圧抵抗メガニズム

応力に対して 3 個の支圧ブロックにモデル化する。

接合幅が小さい場合 $\left(L_{j} \leqq L_{j h}\right)$ のダウェル作用による支圧抵抗 $Q_{d p}$ は， 次式で与えられる。

$$
Q_{d p}=\sigma_{c p} \cdot a_{p} \cdot \Sigma d r=C_{d p} \cdot \sigma_{B p} \cdot a_{p} \cdot n \cdot d r
$$

ここで, 支圧応力 $\sigma_{c p}=C_{d p} \cdot \sigma_{B p}\left(\dot{C}_{d p}\right.$ :支圧係数, $\sigma_{B p}: P C a$ 部コンク

リートの圧縮強度 $), \quad \sum d r=n \times d r(n$ :接合筋の本数, $d r$ 接合筋径 $), a_{p}$ は塑性ヒンジまでの距離。

これより，塑性ヒンジ部における最大曲げモーメントは，接合面に 生じるモーメント $M_{0}$ にコンクリートの支圧応力によるモーメント を加えることにようて，次式のように得られる。

$$
M_{\text {max }}=M_{0}+Q_{d p} \cdot \frac{a_{p}}{2}=\frac{Q_{d p}}{2}\left(L_{j}+a_{p}\right)
$$

塑性ヒンジ部での鉄筋は, ダウェル変形によって完全塑性状態に あり，塑性曲げモーメントと塑性軸力が図 10 に示すように合成応力 を形成していると仮定する。したがって，塑性曲げモーメント $M_{p}$ および塑性軸力 $T_{p}$ は, 次式で与えられる。(文献 17)

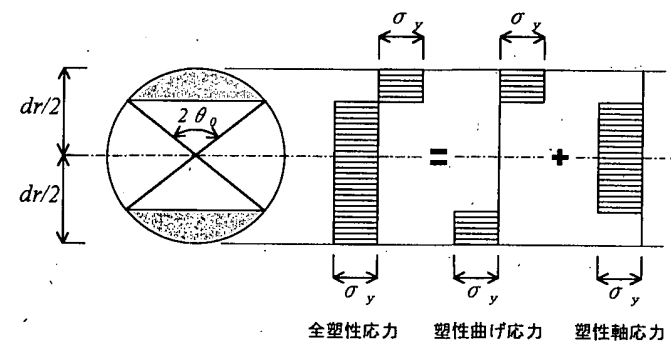

図 10 塑性ヒンジにおける塑性応力分布モデル

$$
M_{p}=C_{M} \cdot \frac{\sigma_{y} \cdot d r^{3}}{6}
$$

$T_{p}=C_{T} \cdot a_{s} \cdot \hat{\sigma}$

ここで， $\Sigma a_{\mathrm{s}} ， \sigma_{y}$ はそれぞれ鉄筋の断面積及び降伏強度を示す。 また低減係数 $C_{M}, C_{T}$ は㳄式によって書き表される。

$$
\begin{aligned}
& C_{M}=\frac{3}{4}\left(\sin \theta_{0}-\frac{1}{3} \sin 3 \theta_{0}\right)\left(C_{M} \leq 1\right) \\
& C_{T}=\frac{2}{\pi}\left(\frac{\pi}{2}-\theta_{0}+\frac{1}{2} \sin 2 \theta_{0}\right)\left(C_{T} \leq 1\right)
\end{aligned}
$$

以上の結果より，釣り合い式 $M_{\max }=M p$ の関係を用いると, (3), (4), (5)式を転換して，接合面から塑性ヒンジまでの距離 $a_{p}$ は，次式のよ うに導かれる。

$$
a_{p}=\frac{L_{j}}{2}\left[\sqrt{1+\frac{4}{3} \cdot \frac{C_{M}}{C_{d p}} \cdot \frac{\sigma_{y}}{\sigma_{B p}} \cdot\left(\frac{d r}{L_{j}}\right)^{2}}-1\right]
$$

接合幅が $0 \mathrm{~mm}$ のときは，(4)式において $L_{j}=0$ とおくと，接合面か ら塑性ヒンジまでの距離 $a_{p 0}$ は, 次式で与えられる。

$$
a_{p 0}=d r \sqrt{\frac{1}{3} \cdot \frac{C_{M}}{C_{d p}} \cdot \frac{\sigma_{y}}{\sigma_{B p}}}
$$

接合幅が大きい場合，接合部コンクリートにおける支圧抵抗 $Q_{d j}$ は，接合面と塑性ヒンジまでの支圧ブロック $\sigma_{c j}$ から，塑性ヒンジ と接合部中央部までの支圧ブロックを差し引いて得られる。

$$
\mathrm{Q}_{\mathrm{dj}}=\sigma_{\mathrm{cj}} \cdot \Sigma \mathrm{dr} \cdot \mathrm{a}_{\mathrm{j}}-\sigma_{\mathrm{cc}} \cdot \Sigma \mathrm{dr} \cdot\left(\frac{\mathrm{L}_{\mathrm{j}}}{2}-\mathrm{a}_{\mathrm{j}}\right)
$$

ここで, $\sigma_{c j}=C_{l i j} \cdot \sigma_{B j}\left(C_{l j}\right.$ :支圧係数, $\sigma_{B j}$ 接合部コンクリートの圧 縮強度), 接合面から塑性ヒンジまでの距離 $a_{j}$ は, 塑性ヒンジに関す るモーメント $\sigma_{c j} \cdot a_{j}^{2} / 2$ と接合筋の塑性曲げモーメント $M_{p}=C_{M} \cdot \sigma_{v}$. $d r^{3} / 6$ との釣り合い式から，次式のように得られ，塑性ヒンジから接 合部コンクリート中央部の支圧応力 $\sigma_{c c}$ は，接合面におけるモーメ ント $M_{0}=0$ になる条件を用いると，次式のように導かれる。

$$
\begin{aligned}
& \mathrm{a}_{\mathrm{j}}=\mathrm{dr} \sqrt{\frac{1}{3} \cdot \frac{\mathrm{C}_{\mathrm{M}}}{\mathrm{C}_{\mathrm{dj}}} \cdot \frac{\sigma_{y}}{\sigma_{\mathrm{B} j}}} \\
& \sigma_{\mathrm{cc}}=\frac{\sigma_{\mathrm{cj}} \cdot \mathrm{a}_{\mathrm{j}}{ }^{2}}{\left(\frac{\mathrm{L}_{\mathrm{j}}^{2}}{4}-\mathrm{a}_{\mathrm{j}}{ }^{2}\right)}
\end{aligned}
$$

(12)及び(13)式を(11)式に代入すると，接合部コンクリートの支圧 抵抗 $Q_{i j}$ は，次式のように導かれる。

$$
\mathrm{Q}_{\mathrm{dj}}=\frac{\mathrm{n} \cdot \mathrm{dr}^{2} \sqrt{\frac{1}{3} \cdot \mathrm{C}_{\mathrm{M}} \cdot \sigma_{\mathrm{Bj}} \cdot \mathrm{C}_{\mathrm{dj}} \cdot \sigma_{\mathrm{y}}}}{\left(1+\frac{2 \mathrm{dr}}{\mathrm{L}_{\mathrm{j}}} \sqrt{\left.\frac{1}{3} \cdot \frac{\mathrm{C}_{\mathrm{M}}}{\mathrm{C}_{\mathrm{dj}} \cdot \frac{\sigma_{\mathrm{z}}}{\sigma_{\mathrm{Bj}}}}\right)}\right.}
$$

得られた支圧抵抗について, 接合幅が小さい場合の(3)式と接合幅 が大きい場合の(14)式を等しいとおくと，接合幅 $L_{j b}$ が近似的に次式 のように導かれる。

$$
L_{j h}=d r \sqrt{\frac{3 C_{y j}}{C_{d j}} \cdot \frac{\sigma_{y}}{\sigma_{B j}}}
$$

これより，接合幅が小さい場合か大きい場合の境界が(15)式から 求められる。以上より，鉄筋のダウェル作用による支圧抵抗は，○く $L_{j} \leqq L_{j b}$ の場合，接合幅が小さい接合部に対応し，(3)式を用いる。 また, $L_{j}>L_{j b}$ なら，接合幅が大きい接合部に対応し，(14)式を用いる。

\subsection{2 接合筋の支圧係数}

接合筋によるダウェル抵抗は，接合筋直下のコンクリートを支承 として局部的な曲げ抵抗に対态する。その時，図 11 の左図に示す ように, 接合筋直下の $P C a$ 部或いは接合部コンクリートでは 3 次元 

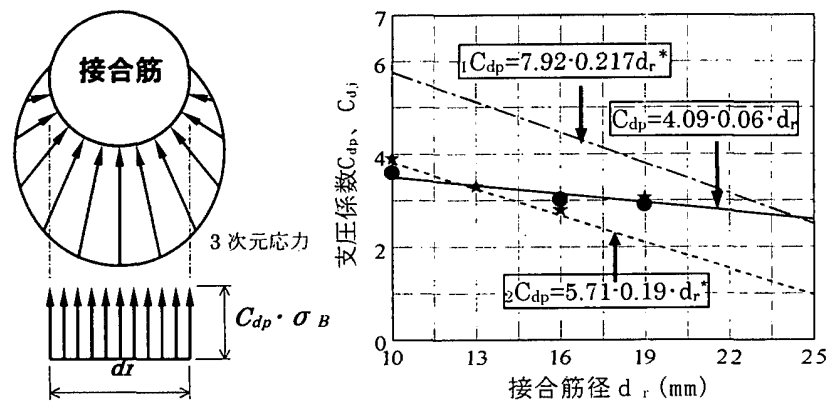

図 11 接合筋径と.支圧係数 $\mathrm{C}_{\mathrm{dp}}, \mathrm{C}_{\mathrm{lj}}$ の関倸

応力状態になり，その抵抗機構は極めて複雑である。既往の研究で は, ${ }_{1} \mathrm{C}_{\mathrm{dp}}=7.92-0.217 \mathrm{dr}$ *文献8(太径)， ${ }_{2} \mathrm{C}_{\mathrm{dp}}=5.71-0.19 \mathrm{dr}^{*}$ *文献 11 (細径)の評 価式を提案した（ここで， $\mathrm{dr}^{*}$ は鉄筋の公称直径)。本実験では，接 合筋径に対する支圧応力は，矩形圧縮応力に置き換えて一様に応力 が生じると仮定する。ここで，接合筋は弾性の梁要素にモデル化し て, 弾性支承上の一端固定梁による曲げモーメントの理論解は，下 式で与えられる(文辣 8.12)。

$$
M=Q_{d j} \cdot e^{-\beta x} \cdot(\sin \beta x-\cos \beta x) / 2
$$

接合面から接合筋の塑性ヒンジ距離 $\mathrm{a}_{1}$ は弾性領域の最大曲げモ メン・トまでの距離と等しいことから,$d M / d x=0$ により,$a_{p}=0.78$ $5 / \beta$ が得られた(就 12 。ここで， $\beta$ は接合部コンクリートの相対剛性

$\beta=\sqrt[4]{k / 4 E_{s} I_{s}}, \mathrm{k}$ はコンクリートの支圧倸数, Rasmussen.B. $\mathrm{H}$ 式(文觔 3) で $\mathrm{k}=2.77 \times 10^{4} \times \mathrm{dr}\left(\mathrm{kgf} / \mathrm{cm}^{2}\right)$, これより，塑性ヒンジ距離 $a_{p}$ を算出する。支圧係数 $C_{d p}, C_{d j}$ を実験結果より回帰分析して接合幅 $0 \mathrm{~mm}$ の試験体の実験結果および(3)式を用いて, 図 11 の右図に示す ように，支圧倸数は次式によって得られた。

$$
C_{d p}=C_{c l j}=4.09-0.06 d r
$$

この式によると，接合筋径が大きくなるにつれて，接合筋直下の コンクリート支圧強度が小さくなる。これは鉄筋径が大きくなると， $\mathrm{C} / \mathrm{dr}$ が小さくなって(C は接合筋のかぶり厚さ), 支圧強度も小さく なると考えられる(文能 16)

\subsection{3 接合筋における曲げ低減俰数 $\mathrm{C}_{\mathrm{M}}$ 及び軸力低減係数 $\mathrm{C}_{\mathrm{T}}$}

接合部におけるせん断抵抗は，図 6 に示すように，接合筋に生じ る曲げ応力と引張応力の組み合わせによってせん断伝達が行われる。 本研究では, 直接せん断実験より $P C a$ 部材間の滑り変位が $2 \mathrm{~mm}$ に 達したとき，最大曲げモーメントを発生した点の鉄筋のひずみを用 いて, 鉄筋の引っ張り実験から得られた履歴曲線に対応して(弾性段 階で式(1)を用いて)，鉄筋の引張軸力を求めた。得られた軸力の値 にばらつきがあるので，最大値と最小值を除いて残りの平均値を用 いて，(6)式から鉄筋の引張による低減係数 $\mathrm{C}_{\mathrm{T}}=0.627$ が得られた。 また, 式(7),(8)を用いて，接合筋の曲げ降伏に対する低減係数 $\mathrm{C}_{\mathrm{M}}=$ 0.589 (図 10 の $\theta_{0}=56.9^{\circ}$ ) となる。

\subsection{4 ダウェル抵抗式の検証}

得られた支圧係数 $C_{d p}, C_{i j}$, 曲げに対する低減係数 $C_{.1}$, ダウェル抵 抗式 $Q_{d p}, Q_{l j}$ を用いて，式(3),(14)によって,各試験体におけるダウエ ル抵抗を計算した。接合幅を考慮したせん断耐力式について実験結 果を用いてその適応性を検証する。図 12 にテフロンシートを施して

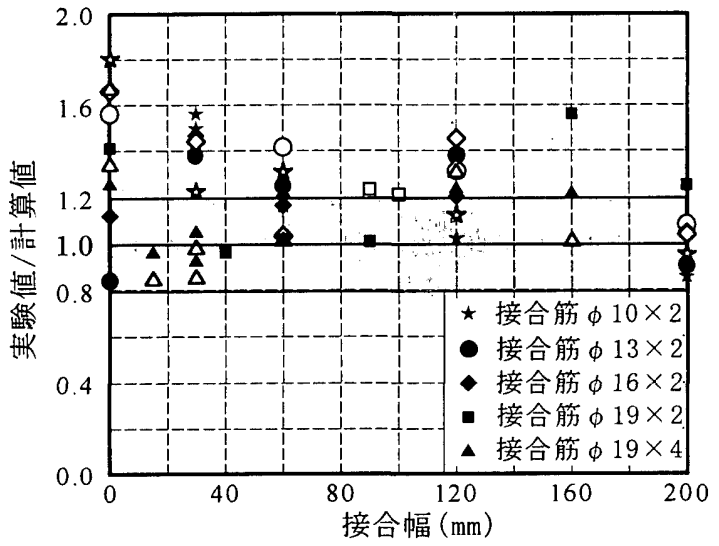

図 12 鉄筋のダウェル作用に対して実験值と計算値の比較

いる試験体の実験値と計算值の関係を示す。ここで, 実験值とは, 直接せん断実験によって得られた正負 $2 つ$ つべり変位 $2 \mathrm{~mm}$ 時耐 力を言い, マークの塗潰しは+サイクル $2 \mathrm{~mm}$ 時附力, マークの白 抜きはーサイクル $2 \mathrm{~mm}$ 時の耐力を示す。これより, 殆どの試験体 は接合幅による影響を良く示しており，かつ安全側に評価されてい ることが確認された。

\section{3 接合筋によるせん断抵抗}

滑り変位によ゙り, プレキャスト部材における接合筋には曲げモー メントの他に引張軸力も生じる。この軸力はコンクリート接合面に 圧縮力を与えて，接合部の滑りにより摩擦力が生じる。試験体 No25 〜34 および試験体 No35〜46に対して, PT シリーズ（表 1 に示すよ うに，PT*ー*試験体はPT シリーズと呼ぶ）試験体では境界面にテフ ロンシートを挿入したため付着力及び摩擦力は無視できる。同一接 合幅の試験体の PN シリーズ(PN*-*試験体は PN シリーズと呼ぶ) と P $\mathrm{T}$ シリーズ試験体の耐力の差は，コンクリート間の付着力を無視す ると, 接合筋が発現する摩擦によるものと考える。PN シリーズと PT シリーズ 22 体試験体における滑り変位時の耐力の差を図 13 に示す。

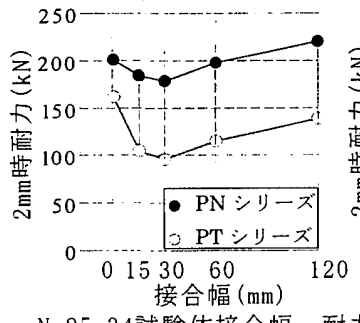

No25-34試験体接合幅一耐力図

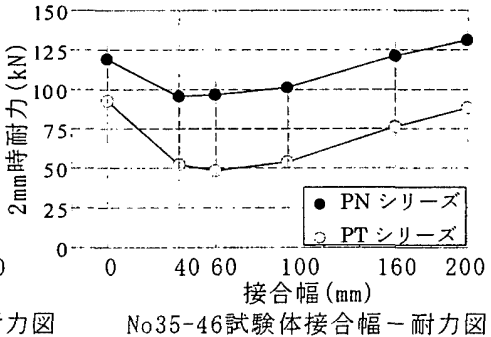

No 35-46試験体接合幅一耐力図

図 13 No25-46 試験体耐力一接合幅関係
この図によると, 滑り変位 $2 \mathrm{~mm}$ 時に, 接合幅 $0 \mathrm{~mm}$ を持つ試験 体を除くと，PN，PTシリーズ試験体に対して耐力の差が，試験体 No25〜34 では 79.8〜83.3KN 前後で, No35〜46 試験体では, 42 . $4 \sim 47.5 \mathrm{KN}$ 前後で接合幅に関倸なく, 大きな違いがない傾向が見ら れた。それより，接合筋による摩擦力 Qc は，接合幅に関係なく， 接合筋断面積に比例して，接合面に作用するものと考えられる。

$\mathrm{PCa}$ 構造要素 (PCa 部) と接合部コンクリートの間の接合面におい てせん断力が作用すると，その破壊メカニズムでは，図 14 に示すよ うに接合部コンクリート内部には, 接合筋の降伏合力 $T_{p}$ と斜めスト 


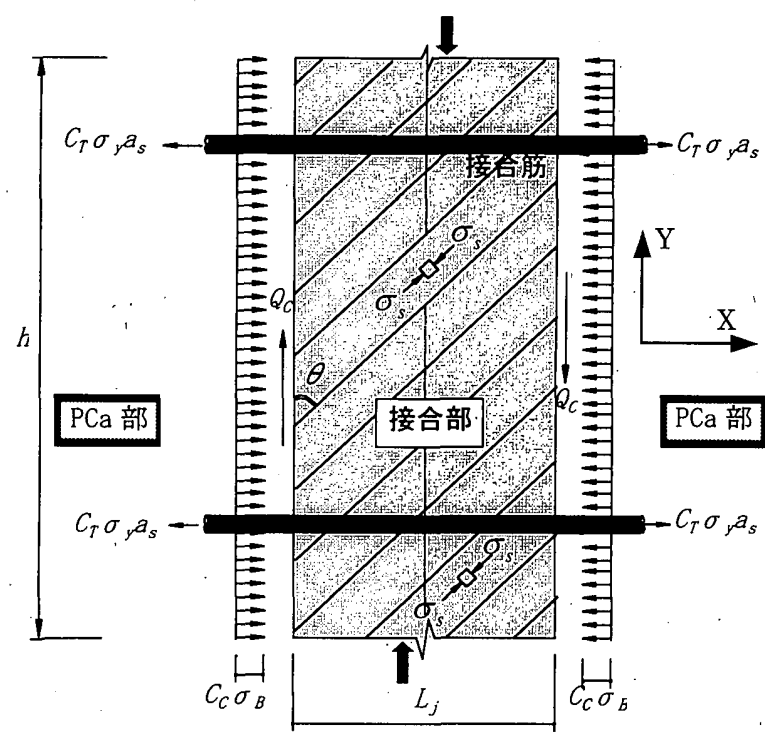

図 14 接合筋せん断摩擦によるストラット機構

ラットに生じる圧縮合力およびせん断摩擦力 $Q_{C}$ が釣り合いを保つ。 軸心と $\theta$ の傾きをもつストラットの中央部で微小要素を考えると, ストラットの圧縮力による応力 $\sigma_{S}$ とせん断力による応力 $\tau_{s}$ が作用 する。これらの応力を接合面の垂直及び水平な応力 $\left(\sigma_{X}, \sigma_{i}, \tau_{N}\right)$ に変換すると, 次式が成り立つ。

$\sigma_{\mathrm{s}}=\sigma_{\mathrm{s}} \sin ^{2} \theta-2 \tau_{\mathrm{s}} \sin \theta \cos \theta$

$\sigma_{y}=\sigma_{s} \cos ^{2} \theta+2 \tau_{s} \sin \theta \cos \theta$

$\tau_{\mathrm{xy}}=\sigma_{\mathrm{s}} \sin \theta \cos \theta-\tau_{\mathrm{s}}\left(\cos ^{2} \theta-\sin ^{2} \theta\right)$

ジョンイントコンクリート部がせん断破壊を生ずる場合, 応力 $\sigma_{y}$ は，接合界面に垂直に作用する応力で， $\sigma_{y}=0$ 。 (18)式から， $\sigma_{s}$ 及 びて $\tau_{\mathrm{xy}}$ は, 次式のように与えられる。

$$
\begin{aligned}
& \sigma_{\mathrm{s}}=\sigma_{\mathrm{x}} \\
& \tau_{\mathrm{xy}}=\frac{1}{2} \sigma_{\mathrm{x}} \cdot \frac{1}{\tan \theta}
\end{aligned}
$$

ここに, せん断力がストラットにおいて一様に分布しているため, $\sigma_{.}=C_{c} \cdot \sigma_{B}, \tau_{, r}=Q_{C} / b h$ である。支圧応力によって接合界面に作用す る圧縮合力 $C_{c} \cdot \sigma_{B} \cdot b \cdot h$ は，接合筋の降伏引張合力 $C_{T} \cdot \sum a_{s} \cdot \sigma_{y}$ 之等 しくなるので, 次式が成り立つ。

$\mathrm{C}_{\mathrm{c}} \cdot \sigma_{\mathrm{B}} \cdot \mathrm{b} \cdot \mathrm{h}=\mathrm{C}_{\mathrm{T}} \cdot \Sigma \mathrm{a}_{\mathrm{s}} \cdot \sigma_{\mathrm{s}}$

ここで， $C_{c}$ は側面部に作用する支圧応力に対する有効係数， $\sum a_{s}$ は接合筋全断面積, $\sigma_{y}$ は接合筋の降伏強度, $b$ は $P C a$ 部の厚さ, $h$ は接合界面に作用する圧縮ストラットの範囲を示す。また係数 $C_{T}$ は，鉄筋が接合界面に作用するせん断力によって引張降伏すること による低滅係数を意味する。

これより，接合界面におけるせん断抵抗は， $Q_{c}=\tau_{x y} \cdot b h$ におい て，(20）及び（21）式を代入すると。次式によって与えられる。

$$
\begin{aligned}
& \mathrm{Q}_{\mathrm{c}}=\frac{\mathrm{C}_{\mathrm{T}} \cdot \sum \mathrm{a}_{\mathrm{s}} \cdot \sigma_{\mathrm{y}}}{2 \tan \theta} \\
& \tan \theta=\frac{\mathrm{C}_{\mathrm{T}} \cdot \sum \mathrm{a}_{\mathrm{s}} \cdot \sigma_{\mathrm{y}}}{2 \mathrm{Q}_{\mathrm{c}}}
\end{aligned}
$$

試験体 No25４6 の実験結果を基に，各試験体において接合筋 が発生した軸力は、概ね $0.21 \sim 0.63 \sum \mathrm{a}_{s} \cdot \sigma_{y}$ の間に変動した。テフロ ンシートを施しているPT シリーズ試験体はテフロンシートを施し
ていないPNシリーズより低い軸力が発生したことが確認された。こ こで、4.2.4 節うらら得られた全試験体における平均軸力低減係数 $\mathrm{C}_{\mathrm{T}}=0.627$ を(23)式に代入すると, 各試験体に形成されるストラット の傾斜角 $\theta$ は， $58.9^{\circ}$ として算出される。ここに各試験体における ストラットの傾斜角は，近似的に $\theta=60^{\circ}$ の值として得られた。こ の值を(22)式に代入すると, 接合面におけるせん断抵抗 $\mathrm{Q}_{c}$ は, 次式 によって与えられる。

$$
\mathrm{Q}_{\mathrm{c}}=0.18 \sum \mathrm{a}_{\mathrm{s}} \cdot \sigma_{\mathrm{s}}
$$

\section{4 シアキーのない $P C a$ 試験体のせん断抵抗式}

実験の結果より, シアキーのない $P C a$ 構造接合部に対して，す心゙ り発生時の静態摩擦力(コンクリート間の付着摩擦力)がすべり発生 以降の動態摩擦力(接合筋のせん断摩擦抵抗) と等しいことから, 接 合幅を持つ $P C a$ 構造接合部におけるせん断抵抗は, 接合筋によるせ ん断摩擦抵抗 $Q_{c}$ と接合筋のダウェル作用によるせん断抵抗 $Q_{d p}$ の果 加で次式のように与えられる。

$$
\begin{aligned}
& L_{j} \leqq L_{j h} \text { の場合 } \\
& Q_{u}=Q_{d p} \longleftarrow Q_{c}=C_{d p} \cdot \sigma_{B p} \cdot a_{p} \cdot n \cdot d r+0.18 \sum a_{s} \cdot \sigma_{y} \\
& L j>L_{j h} \quad \text { の場合 } \\
& \mathrm{Q}_{\mathrm{u}}=\mathrm{Q}_{\mathrm{dj}}+\mathrm{Q}_{\mathrm{c}} \\
& \mathrm{Q}_{\mathrm{u}}=\frac{\mathrm{n} \cdot \mathrm{dr}^{2} \sqrt{0.196 \cdot \sigma_{\mathrm{Bj}} \cdot C_{\mathrm{dj}} \cdot \sigma_{\mathrm{v}}}}{\left(1+\frac{2 \mathrm{dr}}{\mathrm{L}_{\mathrm{j}}} \sqrt{\frac{0.196}{\mathrm{C}_{\mathrm{dj}}} \cdot \frac{\sigma_{\mathrm{v}}}{\sigma_{\mathrm{Bj}}}}\right)}+0.18 \sum \mathrm{a}_{\mathrm{x}} \cdot \sigma_{\mathrm{v}} \\
& \text { ここに } \quad C_{d l p}=C_{d j}=4.09-0.06 d r \\
& a_{p}=\frac{L_{j}}{2}\left[\sqrt{1+\frac{0.785}{C_{d p}} \cdot \frac{\sigma_{y}}{\sigma_{B p}} \cdot\left(\frac{d r}{L_{j}}\right)^{2}}-1\right] \\
& a_{p 0}=0.443 \cdot d r \sqrt{\frac{\sigma_{j}}{C_{d p} \cdot \sigma_{B p}}} \quad\left(\mathrm{~L}_{\mathrm{j}}=0\right) \\
& L_{j h}=d r \sqrt{\frac{1.767}{C_{d i}} \cdot \frac{\sigma_{j}}{\sigma_{B j}}}
\end{aligned}
$$

ここで、 $\mathrm{dr}$ は，接合筋径 $(\mathrm{mm}), \mathrm{n}$ は接合筋の本数， $\mathrm{Lj}$ :は接合幅 ( $\mathrm{mm}), \mathrm{a}_{\mathrm{s}}$ は接合筋断面積 $\left(\mathrm{mm}^{2}\right), \sigma \mathrm{BP}, \sigma \mathrm{Bj}$ はプレキャストおよびジ ヨイントコンクリート压縮強度のうち, いずれか小さい值 $\left(\mathrm{N} / \mathrm{mm}^{2}\right)$ 。 また， $\sigma_{y}$ は接合筋の降伏強度 $\left(\mathrm{N} / \mathrm{mm}^{2}\right) ， \mathrm{~L}_{\mathrm{jb}}$ はダウェル抵抗に対す る境界接合幅 $(\mathrm{mm})$ 。

式(25)，(26)を用いて，シアキーがなく接合幅をもつ PCa 接合部

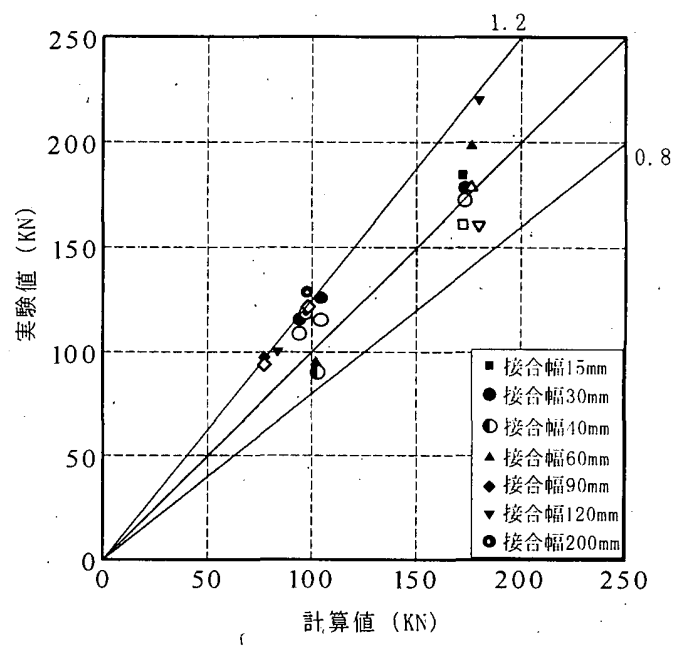

図 15 全せん断抵抗提案式一実験值比較図 
試験体に対して，滑り变位 $2 \mathrm{~mm}$ 時のせん断力を計算した結果を図 15 に示す。ここにマークの塗潰しは+サイクル $2 \mathrm{~mm}$ 時耐力, マー クの白拔きはーサイクル $2 \mathrm{~mm}$ 時の耐力。これより，実験結果は接 合幅によるせん断伝達能力をよく評価していると考えられる。

\section{5. 現行規準式との比較}

シアキーのない $\mathrm{PCa}$ 構造接合部のダウェル作用と鉄筋のせん断 摩擦作用に関する本提案式に対して，ACI(1983 年)式とシアキーの せん断抵抗を含めていない日本建築学会規準式(1982 年)を取り挙げ, 実験結果を用いて検証した。ここで簡便のため，式中の記号を統一 し，改めて耐力式を以下に示す。(文献2)

$\mathrm{ACI}$ せん断式 :

$$
Q_{A C l}=0.85 \cdot \sum A_{s} \cdot \sigma_{y} \cdot \mu
$$

建築学会規準式(鉛直接合部) :

$$
\mathrm{Q}_{\mathrm{AJ}}=\sum \mathrm{A}_{\mathrm{s}} \cdot \sigma_{y}
$$

ここで， $\mu$ 汢摩擦倸数，本実験に対して，普通コンクリートと粗 面仕上げの硬化コンクリートの場合， $\mu=1.0$ とした。本提案式(25) 及び(26)と ACI 式及び AIJ 式を用いて計算された結果と実験值の比 較を図 16 に示す。この図によると，ACI 式及び $\mathrm{AIJ}$ 式を用いて計算 された結果は，接合幅による影響因子が考慮していなく，接合筋の せん断摩擦抵抗のみしか考慮していないために，実験結果に対して 過大評価になっていることが判った。本提案式は，接合幅 0 の試験 体を除いて，相関係数 $=0.928$ の值が得られており，実験結果とよく 対応していることが認められる。ここで、接合幅 0 の試験体の場合、 計算結果が実験結果に対して適応性があまり良くないのは、支圧倸 数 $\mathrm{C}_{\mathrm{d}}$ が過小評価されているためと考えられる。

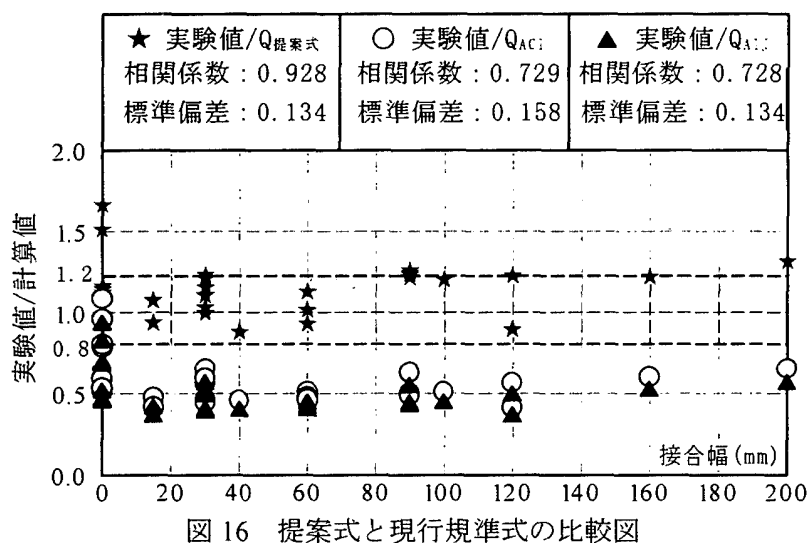

6. まとめ

シアキーの無い $P C a$ 構造接合部におけるせん断実験および解析 を行い，その結果を考察して，以下の事柄が明らかとなった。 1 ·接合幅を有する $P C a$ 接合部試験体に対して，接合幅の違いによっ て，せん断耐力は著しく変動する。

2 ·接合筋の塑性ヒンジは，接合幅が小さい $(L<L j)$ 場合，接合界面を 挟んで， $P C a$ 部左右 2 個所に生じ，接合幅が大きい $(L>L j)$ 場合 ，2 つの境界面に左右 4 個所に生じる。

3·接合幅に対応して，接合筋のダウェル作用による抵抗メガニズム 機構が構成され，コンクリートの支圧によるダウェルせん断伝達 機構の解明が試みられ，導かれた評価式は，実験結果とよく対応
することが認められた。

4·接合筋によって接合面に作用するせん断摩摖は, 圧縮ストラット を用いたせん断伝達機構によってモデル化され，接合幅に関係な く，ほぼ一定の值を示すことが認められる。

5 ·既往の PCa 構造接合部のせん断耐力は, 一面せん断式であるので ，接合幅を有する接合部に対して過大評価の傾向が見られる。

\section{謝辞}

本研究をまとめるに際し、武蔵工業大学望月重教授からデータの提 供及び貴重な助言を頂きました。ここに記して感謝の意を表します。

\section{参考文献}

1）日本建築学会編「鉄筋コンクリート構造計算基準・同解説」 1999 年.

2）日本建築学会編「壁式プレキャスト構造鉄筋コンクリート造設計基準・同 解説」 1982 年.

3) Rasmussen, B. H. : The Carrying Capacity of Tranceversely Loaded Bolts and Dowels Embedded in Concrete, Bygings Statiske Meddelser, Vol. 34, No. 2, 1963.

4) A.H. Mattock: Shear Transfer in concrete Having Reinfocement at an Angle to the Shear Plane, Shear in Reinfoced concrete (Vol. 1), pp. 17 $\sim 42$, ACI Publication SP-42, 1974.

5) Jensen. B.C. : On the Ultimate Load of Vertical, Keyed Shear Joints in Large Panel Buildings, Technical University of Denmark. Institufe of Building Design Report, No. 108, p. 1 8, 1975

6) Shuang XIE, Eiji MAKITANI, Syouhei OGAWA : The Dowel Action of Steel Bars in the Joint Connection of Precast Reinforced Concrete, Proceeding of the Japan Concrete Institute, Vol.6, No.2, p.835 $840,1994$.

7)梖谷榮次・小川祥平・謝㷋: 接合幅を有するプレキャスト部材接合部のダウ エル筋のせん断伝達（その1〜2), 日本建築学会大会学術講演梗概集 (北陸) 1994 年 9 月, p. 761 764.

8) 橹谷榮次・小川祥平:プレキャスト部材接合部におけるダウェル筋のせん 断伝達能力, コンクリートエ学年次論文集, Vol. 15, 1993, p601〜605.

9）大西昭徳・植谷栄次·謝爽：プレキャスト鉄筋コンクリート部材接合面にお けるせん断伝達に関する研究, 日本建築学会大会学術講演梗概集 (近畿) 1996 年 9 月, p. 853 854.

10) 小野寺知子・梖谷栄次・水上明·謝爽:シアキーを有する PCa 構造接合部に おけるせん断伝達に関する研究(その1，その2)，日本建築学会大会講演梗 概集 (九州), 1998 年 9 月, p. 759〜762.

11）斎䪓・橿谷栄次・水上明他:シアキーを有する $\mathrm{PCa}$ 構造接合部におけるせん 断伝達に関する研究 (その 3, その 4, その 5.), 日本建築学会大会講演梗概 集 (中国), 1999 年 9 月, p. 461 466.

12) Shuang Xie, Eiji Makitani: The Dowel Action of Steel Bars in the Joint Connection of Precast Reinforced Concrete. Concrete Jounal of JCI, Vol. 16, 1994 , p. $825 \sim 840$.

13）吉野次彦・槙谷栄次・松崎育弘・石橋一彦・永坂具也：プレキャス卜部材接 合面の性能に関寸る研究（その1, その2, その3）, 日本建築学会大会講演 梗概集 (北海道)，1995 年 8 月, p. 643 648,

14）望月重・他:ジョイント幅を考虑した接合部のせん断耐力の実験, 日本建 築学会大会学術講演梗概集 (北陸)，1992 年 8 月, p. 771 〜 772,

15) 大淵英夫・中野克彦・松崎育弘・他：ずれ変形を考慮したブレキャスト部材 接合面にお汁るせん断伝達に関する研究, 日本建築学会構造系論文, 491 号 1997 年 6 月, p. 97〜104

16)日本建築学会編「鉄筋コンクリート終局強度に関する資料」, 1987 年, P90

17）望月重・梖谷榮次·永坂具也：「壁式ブレキャスト鉄筋コンクリート造鉛直 接合部のせん断耐力」日本建築学会構造系論文集，第 424 号，1991 年 6 月, p. $11 \sim$ p22

18）日本建築学会編:プレキャスト鉄筋コンクリート構造の設計と施工, 1986 19) W. F. Chen:Plasticity in Reinforced Concrete, NcGraow-Hill Internat ional Book Company, 1982 